ORIGINAL ARTICLE / ARTIGO ORIGINAL

Socioeconomic inequalities related to noncommunicable diseases and their limitations: National Health Survey, 2019

\title{
Desigualdades socioeconômicas relacionadas às doenças crônicas não transmissíveis e suas limitações: Pesquisa Nacional de Saúde, 2019
}

\author{
Deborah Carvalho Maltal (D), Regina Tomie Ivata Bernal' (D), \\ Margareth Guimaraes Lima" (D), Alanna Gomes da Silva' (D), \\ Célia Landmann Szwarcwald"I' (D), Marilisa Berti de Azevedo Barros ${ }^{\mathrm{IV}}$ (1)
}

\begin{abstract}
Objective: to analyze socioeconomic inequalities in the self-reported prevalence of NonCommunicable Diseases (NCDs) and their disabilities in the Brazilian adult population. Methods: Cross-sectional study with data from the National Health Survey carried out in 2019. The self-reported prevalences of individuals with some noncommunicable diseases were calculated, according to sociodemographic characteristics; and the prevalence and prevalence ratio of these diseases and degrees of disability, according to education and possession of a private health plan. Results: $47.6 \%$ of the population reported having at least one noncommunicable diseases. Noncommunicable diseases increased progressively with age and were more prevalent in women (PR 1.13; 95\%CI 1.1-1.15), in black (PR 1.04; 95\%CI 1.01-1, 06) or brown individuals (PR 1.05; 95\%CI 1.01-1.09), illiterate or with incomplete elementary education (PR 1.12; 95\%CI 1.08-1.16), in the Southeast (PR 1.10; 95\%CI 1.051.14 ) and the South (PR 1.07; 95\%CI 1.03-1.12) and among individuals who do not have private health insurance (PR 1.02; 95\%CI 1.0-1.05). For the majority of noncommunicable diseases investigated, the highest reports of disabilities were among those with low education and without health insurance. Conclusion: adults with less education and without private health plans have a higher prevalence of noncommunicable diseases and a higher degree of disability. Thus, it is important to analyze health indicators in the face of different populations and disparities, in order to understand and monitor health inequalities.
\end{abstract}

Keywords: Chronic disease. Disabled persons. Health status disparities. Socioeconomic factors.

\footnotetext{
Postgraduate Program in Nursing, School of Nursing, Universidade Federal de Minas Gerais - Belo Horizonte (MG), Brazil. "Department of Public Health, Universidade Estadual de Campinas - Campinas (SP), Brazil.

"IIInstituto de Comunicação e Informação Cientíica e Tecnológica em Saúde, Fundação Oswaldo Cruz - Rio de Janeiro (RJ), Brazil. IVSchool of Medical Sciences, Universidade Estadual de Campinas - Campinas (SP), Brazil.

Conflict of interests: nothing to declare - Financial support: Fundo Nacional de Saúde. Secretaria de Vigilância em Saúde, Ministry of Health - TED 66/2018.
} 
RESUMO: Objetivo: Analisar as desigualdades socioeconômicas na prevalência autorreferida de doenças crônicas não transmissíveis e suas limitações na população adulta brasileira. Métodos: Estudo transversal com dados da Pesquisa Nacional de Saúde realizada em 2019. Calcularam-se as prevalências autorreferidas de indivíduos com alguma doença crônica não transmissível, segundo características sociodemográficas, e as prevalências e a razão de prevalência dessas doenças e seus graus de limitações, segundo escolaridade e posse de plano de saúde privado. Resultados: 47,6\% da população relatou ter pelo menos uma doença crônica não transmissível. As doenças crônicas não transmissíveis aumentaram progressivamente com a idade e foram mais prevalentes nas mulheres (RP 1,13; IC95\% 1,10-1,15), nos indivíduos pretos (RP 1,04; IC95\% 1,01-1,06) ou pardos (RP 1,05; IC95\% 1,011,09 ), analfabetos ou com ensino fundamental incompleto (RP 1,12; IC95\% 1,08-1,16), nos moradores das regiões Sudeste (RP 1,10; IC95\% 1,05-1,14) e Sul (RP 1,07; IC95\% 1,03-1,12) e entre os indivíduos que não possuem plano de saúde privado (RP 1,02; IC95\% 1,00-1,05). Para a maioria das doenças crônicas não transmissíveis investigadas, a maior prevalência do relato de limitação esteve entre aqueles com baixa escolaridade e sem plano de saúde. Conclusão: Adultos com menor escolaridade e sem planos de saúde privados apresentam maior prevalência de doenças crônicas não transmissíveis e maior grau de limitação. É importante avaliar os indicadores de saúde ante as diferentes populações e desigualdades, a fim de diagnosticar e monitorar as iniquidades em saúde.

Palavras-chave: Doença crônica. Pessoas com deficiência. Desigualdades em saúde. Iniquidade social.

\section{INTRODUCTION}

The epidemic of noncommunicable diseases (NCDs) results in devastating consequences for individuals, their families, and communities, in addition to overburdening health systems ${ }^{1}$.

NCDs are one of the biggest global health problems, responsible for 41 million deaths in the world $(71 \% \text { of all deaths) })^{2}$. Of these deaths, 15 million are premature ( $<70$ years of age). The burden of these diseases is greater in low- and medium-low-income countries, and in Brazil, NCDs are the most frequent causes and accounted for approximately $76 \%$ of the causes of death in $2017^{3}$.

Evidence indicates a proportional increase in NCDs due to the growth of the four main risk factors (tobacco, physical inactivity, alcohol abuse, and unhealthy diets) and also to population aging. Thus, interventions on risk factors would result in a reduction in the number of deaths, in addition to improving the quality of life and health ${ }^{4,5}$.

NCDs more frequently affect low-income populations, as they are more vulnerable, exposed to risks, and have less access to health services and health promotion and disease prevention practices. People with NCD have their poverty situation aggravated by family expenses with the disease ${ }^{6}$. Studies show that social determinants, such as education, occupation, income, gender, and ethnicity contribute to the increase in NCDs and morbidity and mortality ${ }^{4,7}$. Socioeconomic differences result in harm to people in conditions of greater social vulnerability, increasing their limitations and health inequity ${ }^{8,9}$. 
In this context, knowledge of the population's health situation is the first step to plan actions and programs that reduce the occurrence and severity of NCDs. Monitoring health indicators is essential to assess trends in the health situation, aiming to identify the evolution of health inequalities ${ }^{10}$. Analyzing this information is also a way to support the monitoring of international commitments, such as the 2030 Agenda of the Sustainable Development Goals (SDGs) ${ }^{11}$.

In light of the above, the aim of this study was to analyze socioeconomic inequalities in the self-reported prevalence of NCDs and the limitations resulting from these morbidities in the Brazilian adult population.

\section{METHODS}

This is a cross-sectional study with data from the 2019 National Health Survey (Pesquisa Nacional de Saúde-PNS), which is a population-based survey, representative of the Brazilian population, carried out by the Brazilian Institute of Geography and Statistics (Instituto Brasileiro de Geografia e Estatística - IBGE) in partnership with the Ministry of Health ${ }^{12}$.

The research used a probabilistic cluster sample in three stages, with the census tracts being the primary unit, the households the secondary, and a resident aged 15 years old or older, randomly selected from each household, the tertiary. Households and residents were selected by simple random sampling. The target population of the 2019 PNS was individuals aged 15 years old or older, residing in permanent private households. However, for the analyses of the present study, individuals under 18 years of age were excluded, thus, the final sample consisted of 88,531 individuals. Methodological details can be obtained from PNS publications ${ }^{12,13}$.

The diseases considered as NCDs were: arterial hypertension; diabetes; heart disease; stroke; asthma; arthritis or rheumatism; chronic back problem; work-related musculoskeletal disorder (WMSD); chronic lung disease (pulmonary emphysema, chronic bronchitis or COPD), cancer; chronic renal failure. The presence of a self-reported diagnosis of hypertension was evaluated by the following question: "Has any doctor ever given you the diagnosis of arterial hypertension?”, and thus the self-reported diagnoses were successively evaluated for the other diseases mentioned above, with the exception of chronic back problem, which was evaluated by the question: "Do you have any chronic back problems, such as chronic back or neck pain, low back pain, sciatica, problems in the vertebrae or disc?”.

Regarding the degree of limitation in usual activities, the following question is asked: "In general, to what degree does hypertension or some complication of hypertension limit your usual activities (such as working, studying, doing housework, etc.)?”. Answer options are:

1. Does not limit;

2. A little;

3. Moderately; 
4. Deeply;

5. Very deeply.

Thus, it went on for all the aforementioned diseases. For this study, only the answers "Deeply" and "Very deeply" were considered.

The following estimates were calculated: prevalence of individuals who reported a diagnosis of at least one NCD, according to sociodemographic variables: gender, age, education, race/color, region, and having a private health insurance; prevalence and prevalence ratio (PR) for each NCD, according to education level and private health insurance; and prevalence of deep or very deep limitations caused by NCDs, also according to education level and private health insurance.

Analyses included estimates of prevalence rates and respective 95\% confidence intervals (95\%CI) and crude and adjusted PR (PRadj) by gender, age, and region, obtained using Poisson regression with robust variance. All analyses were performed using the Data Analysis and Statistical Software (Stata), version 14, using the survey module that considers the post-stratification weights.

The PNS was approved by the National Research Ethics Commission (Comissão Nacional de Ética em Pesquisa - CONEP) of the Ministry of Health, under opinion number 3.529.376. The adult's participation in the research was voluntary, and the confidentiality of the information was guaranteed. PNS 2019 data is available for public access and use.

\section{RESULTS}

The results revealed that $47.6 \%$ of the Brazilian adult population reported at least one NCD. Prevalences were higher in women (PR 1.13; 95\%CI 1.10-1.15) and progressively increased with age. Black (PR 1.04; 95\%CI 1.01-1.06) or brown (RP 1.05; 95\%CI 1.01-1.09) and illiterate or with incomplete elementary/middle education (PR 1.12; 95\%CI 1.08-1.16) individuals also showed higher prevalences. NCDs were more prevalent in the Southeast (PR 1.10; 95\%CI 1.05-1.14) and South (RP 1.07; 95\%CI 1.03-1.12) and among individuals who do not have a private health insurance (PR 1.02; 95\%CI 1.00-1.05) (Table 1). On the other hand, they were less prevalent among those with higher income, above three minimum wages (PR 0.94; 95\%CI 0.91-0.98) (data not shown).

Table 2 shows the prevalence and adjusted PR of each NCD, according to education. For most diseases, the highest prevalence occurred in individuals with low or no education, compared to the population with complete higher education: hypertension (PR 1.38; 95\%CI 1.29-1.46), diabetes (PR 1.77; 95\%CI 1.56-2.02), heart disease (PR 1.27; 95\%CI 1.10-1.47), stroke (PR 2.71; 95\%CI 2.06-3.57), rheumatism (PR 1.35; 95\%CI 1.18-1.55), back problems (PR 1.37; 95\%CI 1.28-1.48), chronic lung disease (PR 1.61; CI95 \% 1.16-2.23). However, other diseases such as asthma (PR 0.75; CI 95\% 0.64-0.88), WMSD (PR 0.94; CI 95\% 0.73-1.21) and cancer (PR 0.64; CI 95\% 0.54-0.77), were less prevalent in these individuals. 
Table 1. Self-reported prevalence and crude and adjusted prevalence ratio of having at least one noncommunicable disease, according to sociodemographic characteristics. National Health Survey, 2019.

\begin{tabular}{|c|c|c|c|c|c|c|c|}
\hline & & $P$ & $95 \% \mathrm{Cl}$ & $\mathrm{PR}_{\text {crude }}$ & $95 \% \mathrm{Cl}$ & $\mathrm{PR}_{\mathrm{adj}}$ & $95 \% \mathrm{Cl}$ \\
\hline & Total & 47.63 & & & & & \\
\hline & Male & 43.73 & $42.84-44.62$ & 1.00 & & 1.00 & \\
\hline Veriuet & Female & 51.06 & $50.21-51.91$ & 1.17 & $1.14-1.20$ & 1.13 & $1.1-1.15$ \\
\hline & $18-24$ & 20.62 & $18.98-22.25$ & 1.00 & & 1.00 & \\
\hline & $25-34$ & 25.28 & $24.01-26.54$ & 1.23 & $1.12-1.34$ & 1.22 & $1.12-1.34$ \\
\hline Age & $35-44$ & 38.51 & $37.25-39.76$ & 1.87 & $1.72-2.03$ & 1.86 & $1.71-2.02$ \\
\hline (yea & $45-54$ & 55.21 & $53.55-56.87$ & 2.68 & $2.46-2.91$ & 2.66 & $2.44-2.89$ \\
\hline & $55-64$ & 69.91 & $68.58-71.24$ & 3.39 & $3.13-3.67$ & 3.36 & $3.10-3.64$ \\
\hline & 65 and more & 80.73 & $79.74-81.72$ & 3.92 & $3.62-4.24$ & 3.86 & $3.56-4.18$ \\
\hline & White & 49.42 & $48.45-50.38$ & 1.00 & & 1.00 & \\
\hline Race/ & Black & 45.85 & $44.94-46.75$ & 0.93 & $0.90-0.95$ & 1.04 & $1.01-1.06$ \\
\hline Color & Brown & 47.66 & $45.99-49.33$ & 0.96 & $0.93-1.00$ & 1.05 & $1.01-1.09$ \\
\hline & Others & 47.97 & $42.66-53.28$ & 0.97 & $0.87-1.09$ & 0.99 & $0.91-1.07$ \\
\hline & $\begin{array}{l}\text { Complete } \\
\text { Higher degree }\end{array}$ & 44.11 & $42.63-45.60$ & 1.00 & & 1.00 & \\
\hline & $\begin{array}{c}\text { High School/ } \\
\text { Incomplete Higher } \\
\text { Degree }\end{array}$ & 37.37 & $36.29-38.46$ & 0.85 & $0.81-0.88$ & 1.00 & $0.96-1.03$ \\
\hline Education & $\begin{array}{c}\text { Elementary/Middle } \\
\text { School/Incomplete } \\
\text { High School }\end{array}$ & 42.73 & $41.17-44.30$ & 0.97 & $0.92-1.02$ & 1.07 & $1.02-1.12$ \\
\hline & $\begin{array}{l}\text { Illiterate/ } \\
\text { Incomplete } \\
\text { Elementary/ } \\
\text { Middle School }\end{array}$ & 61.58 & $60.56-62.60$ & 1.40 & $1.34-1.45$ & 1.12 & $1.08-1.16$ \\
\hline & North & 40.98 & $39.46-42.50$ & 1.00 & & 1.00 & \\
\hline & Northeast & 45.87 & $44.86-46.87$ & 1.12 & $1.07-1.17$ & 1.04 & $1.00-1.90$ \\
\hline Region & Southeast & 50.09 & $48.87-51.31$ & 1.22 & $1.17-1.28$ & 1.10 & $1.05-1.14$ \\
\hline & South & 49.10 & $47.65-50.55$ & 1.20 & $1.14-1.26$ & 1.07 & $1.03-1.12$ \\
\hline & Centro-Oeste & 43.69 & $42.20-45.18$ & 1.07 & $0.03-1.12$ & 1.06 & $0.03-1.12$ \\
\hline Health & Yes & 46.52 & $45.79-47.25$ & 1.00 & & 1.00 & \\
\hline & No & 50.62 & $49.37-51.87$ & 1.09 & $1.06-1.12$ & 1.02 & $1.00-1.05$ \\
\hline
\end{tabular}

P: self-reported prevalence; $\mathrm{PR}_{\text {crude }}$ : crude prevalence ratio; $\mathrm{PR}_{\text {adj }}$ : adjusted prevalence ratio. 
Table 2. Prevalence and prevalence ratio of having a noncommunicable disease, according to education. National Health Survey, 2019.

\begin{tabular}{|c|c|c|c|c|c|}
\hline NCD & Measures & a & b & c & $d$ \\
\hline \multirow{2}{*}{ Hypertension } & $\mathrm{P}$ & 36.55 & 20.38 & 15.44 & 18.17 \\
\hline & $\mathrm{PR}^{*}(95 \% \mathrm{Cl})$ & $1.38(1.29-1.46)$ & $1.30(1.21-1.41)$ & $1.13(1.06-1.22)$ & 1.00 \\
\hline \multirow{2}{*}{ Diabetes } & $P$ & 12.89 & 6.26 & 4.58 & 4.65 \\
\hline & $\mathrm{PR}^{*}(95 \% \mathrm{Cl})$ & $1.77(1.56-2.02)$ & $1.55(1.31-1.82)$ & $1.34(1.16-1.54)$ & 1.00 \\
\hline \multirow{2}{*}{$\begin{array}{l}\text { Heart } \\
\text { disease }\end{array}$} & $P$ & 7.83 & 4.78 & 3.47 & 4.25 \\
\hline & $\mathrm{PR}^{*}(95 \% \mathrm{Cl})$ & $1.27(1.10-1.47)$ & $1.25(1.04-1.51)$ & $1.05(0.89-1.23)$ & 1.00 \\
\hline \multirow{2}{*}{ Stroke } & $P$ & 3.77 & 1.65 & 0.80 & 0.82 \\
\hline & $\mathrm{PR}^{*}(95 \% \mathrm{Cl})$ & $2.71(2.06-3.57)$ & $2.21(1.53-3.19)$ & $1.27(0.93-1.73)$ & 1.00 \\
\hline \multirow{2}{*}{ Asthma } & $P$ & 4.44 & 5.58 & 5.32 & 6.69 \\
\hline & $\mathrm{PR}^{*}(95 \% \mathrm{Cl})$ & $0.75(0.64-0.88)$ & $0.82(0.68-0.98)$ & $0.75(0.65-0.88)$ & 1.00 \\
\hline \multirow{2}{*}{ Rheumatism } & $P$ & 11.65 & 6.15 & 4.91 & 5.78 \\
\hline & $\mathrm{PR}^{*}(95 \% \mathrm{Cl})$ & $1.35(1.18-1.55)$ & $1.25(1.07-1.45)$ & $1.15(1.02-1.31)$ & 1.00 \\
\hline \multirow{2}{*}{$\begin{array}{l}\text { Spine/back } \\
\text { problem }\end{array}$} & $P$ & 29.16 & 18.18 & 16.79 & 18.63 \\
\hline & $\mathrm{PR}^{*}(95 \% \mathrm{Cl})$ & $1.37(1.28-1.48)$ & $1.09(0.99-1.19)$ & $1.04(0.96-1.13)$ & 1.00 \\
\hline \multirow{2}{*}{ WMSD } & $P$ & 2.39 & 2.36 & 2.52 & 2.89 \\
\hline & $\mathrm{PR}^{*}(95 \% \mathrm{Cl})$ & $0.94(0.73-1.21)$ & $1.04(0.77-1.41)$ & $1.12(0.91-1.38)$ & 1.00 \\
\hline \multirow{2}{*}{$\begin{array}{l}\text { Lung } \\
\text { disease }\end{array}$} & $\mathrm{P}$ & 2.18 & 1.67 & 1.32 & 1.30 \\
\hline & $\mathrm{PR}^{*}(95 \% \mathrm{Cl})$ & $1.61(1.16-2.23)$ & $1.40(0.98-2.01)$ & $1.15(0.81-1.64)$ & 1.00 \\
\hline \multirow{2}{*}{ Cancer } & $\mathrm{P}$ & 3.28 & 1.93 & 1.77 & 3.28 \\
\hline & $\mathrm{PR}^{*}(95 \% \mathrm{Cl})$ & $0.64(0.54-0.77)$ & $0.68(0.52-0.90)$ & $0.76(0.63-0.91)$ & 1.00 \\
\hline \multirow{2}{*}{$\begin{array}{l}\text { Kidney } \\
\text { disease }\end{array}$} & $P$ & 1.98 & 1.72 & 1.08 & 0.98 \\
\hline & $\mathrm{PR}^{*}(95 \% \mathrm{Cl})$ & $1.68(1.21-2.34)$ & $1.87(1.28-2.74)$ & $1.27(0.9-1.78)$ & 1.00 \\
\hline
\end{tabular}

When analyzing the degree of deep or very deep limitation in usual activities caused by NCDs, according to the level of education, it was also found that the prevalence of limitations is higher among the less educated and can be two to four times higher when comparing with those with higher education (Table 3).

Table 4 shows the prevalence and adjusted PR for having NCDs and deep or very deep limitation in usual activities, according to ownership of a private health insurance. Brazilians who do not have a private health insurance have a higher prevalence for all NCDs surveyed: hypertension (PR 1.85; 95\%CI 1.34-2.57), diabetes (PR 1.88; 95\%CI 
Table 3. Prevalence and prevalence ratio of very deep or deep limitation, according to educational level. National Health Survey, 2019.

\begin{tabular}{|c|c|c|c|c|c|c|}
\hline NCD & Measures & Total & a & b & c & d \\
\hline \multirow{3}{*}{ Hypertension } & $P$ & 3.01 & 4.08 & 2.96 & 1.59 & 0.98 \\
\hline & $\mathrm{PR}^{*}$ & & 2.30 & 3.01 & 1.57 & 1.00 \\
\hline & $95 \% \mathrm{Cl}$ & & $(2.30-8.41)$ & $(1.45-6.22)$ & $(0.78-3.16)$ & \\
\hline \multirow{3}{*}{ Diabetes } & $P$ & 5.83 & 7.31 & 4.02 & 4.51 & 1.97 \\
\hline & $\mathrm{PR}^{*}$ & & 4.01 & 2.16 & 2.30 & 1.00 \\
\hline & $\mathrm{PR}^{*}$ & & $1.72-9.36$ & $0.87-5.34$ & $0.92-5.74$ & \\
\hline \multirow{3}{*}{$\begin{array}{l}\text { Heart } \\
\text { disease }\end{array}$} & $95 \% \mathrm{Cl}$ & 11.90 & 16.33 & 11.54 & 6.53 & 4.01 \\
\hline & $\mathrm{PR}^{*}$ & & 3.93 & 3.08 & 1.79 & 1.00 \\
\hline & $95 \% \mathrm{Cl}$ & & $1.87-8.23$ & $1.39-6.85$ & $0.83-3.86$ & \\
\hline \multirow{3}{*}{ Stroke } & $P$ & 20.88 & 24.55 & 11.13 & 16.12 & 11.99 \\
\hline & $\mathrm{PR}^{*}$ & & 1.96 & 1.03 & 1.44 & 1.00 \\
\hline & $95 \% \mathrm{Cl}$ & & $1.10-3.51$ & $0.48-2.2$ & $0.74-2.80$ & \\
\hline \multirow{3}{*}{ Asthma } & $P$ & 6.39 & 10.89 & 6.33 & 4.40 & 3.34 \\
\hline & $\mathrm{PR}^{*}$ & & 3.22 & 1.98 & 1.39 & 1.00 \\
\hline & $95 \% \mathrm{Cl}$ & & (1.73-5.97) & $(0.97-4.06)$ & $(0.74-2.63)$ & \\
\hline \multirow{3}{*}{ Rheumatism } & $P$ & 20.00 & 25.81 & 18.55 & 12.14 & 10.41 \\
\hline & $\mathrm{PR}^{*}$ & & 2.47 & 1.80 & 1.21 & 1.00 \\
\hline & $95 \% \mathrm{Cl}$ & & (1.82-3.37) & $(1.24-2.61)$ & $(0.85-1.72)$ & \\
\hline \multirow{3}{*}{$\begin{array}{l}\text { Spine/back } \\
\text { problem }\end{array}$} & $P$ & 16.09 & 20.86 & 16.36 & 11.58 & 8.44 \\
\hline & $\mathrm{PR}^{*}$ & & 2.36 & 2.07 & 1.50 & 1.00 \\
\hline & $95 \% \mathrm{Cl}$ & & $(1.91-2.92)$ & $(1.62-2.66)$ & $(1.17-1.91)$ & \\
\hline \multirow{3}{*}{ WMSD } & $P$ & 17.59 & 28.25 & 20.78 & 11.06 & 8.41 \\
\hline & $\mathrm{PR}^{*}$ & & 2.83 & 2.63 & 1.41 & 1.00 \\
\hline & $95 \% \mathrm{Cl}$ & & $(1.67-4.80)$ & $(1.45-4.77)$ & $(0.82-2.41)$ & \\
\hline \multirow{3}{*}{$\begin{array}{l}\text { Lung } \\
\text { disease }\end{array}$} & $P$ & 14.00 & 20.28 & 12.10 & 8.53 & 5.46 \\
\hline & $\mathrm{PR}^{*}$ & & 2.95 & 2.09 & 1.54 & 1.00 \\
\hline & $95 \% \mathrm{Cl}$ & & (1.32-6.59) & $(0.77-5.66)$ & $(0.64-3.68)$ & \\
\hline \multirow{3}{*}{ Cancer } & $P$ & 11.09 & 12.17 & 16.44 & 13.49 & 3.08 \\
\hline & $\mathrm{PR}^{*}$ & & 4.67 & 6.32 & 4.49 & 1.00 \\
\hline & $95 \% \mathrm{Cl}$ & & $(2.17-10.04)$ & $(2.40-16.6)$ & $(1.95-10.31)$ & \\
\hline \multirow{3}{*}{$\begin{array}{l}\text { Kidney } \\
\text { disease }\end{array}$} & $P$ & 12.17 & 15.54 & 13.93 & 8.17 & 4.09 \\
\hline & $\mathrm{PR}^{*}$ & & 4.14 & 2.90 & 1.86 & 1.00 \\
\hline & $95 \% \mathrm{Cl}$ & & $(1.50-11.45)$ & $(0.95-8.86)$ & $(0.60-5.79)$ & \\
\hline
\end{tabular}

P: self-reported prevalence; PR: prevalence ratio; NCD: noncommunicable diseases; *PR: prevalence ratio adjusted by age, gender, and region. a: Complete higher degree; b: Complete high school/incomplete higher degree; c: Complete elementary/middle school/incomplete high school; d: illiterate/incomplete elementary/middle school. 
Table 4. Prevalence and prevalence ratio of having a noncommunicable disease and deep or very deep limitation, according to private health insurance. National Health Survey, 2019.

\begin{tabular}{|c|c|c|c|c|c|c|}
\hline \multirow{2}{*}{ NCD } & \multirow{2}{*}{ Measures } & \multicolumn{2}{|c|}{ Health insurance } & \multirow{2}{*}{$\begin{array}{l}\text { Limitation } \\
\qquad(P)\end{array}$} & \multicolumn{2}{|c|}{ Health insurance } \\
\hline & & No & Yes & & Yes & No \\
\hline \multirow{2}{*}{ Hypertension } & $P$ & 23.77 & 24.34 & 3.01 & 1.79 & 3.47 \\
\hline & $\mathrm{PR}^{*}(95 \% \mathrm{Cl})$ & $1.85(1.34-2.57)$ & 1.00 & & 1.00 & $1.85(1.34-2.57)$ \\
\hline \multirow{2}{*}{ Diabetes } & $P$ & 7.67 & 7.88 & 5.83 & 3.65 & 6.67 \\
\hline & $\mathrm{PR}^{*}(95 \% \mathrm{Cl})$ & $1.88(1.22-2.89)$ & 1.00 & & 1.00 & $1.88(1.22-2.89)$ \\
\hline \multirow{2}{*}{ Heart disease } & $\mathrm{P}$ & 2.14 & 1.46 & 11.90 & 6.90 & 14.23 \\
\hline & $\mathrm{PR}^{*}(95 \% \mathrm{Cl})$ & $2.15(1.55-2.97)$ & 1.00 & & 1.00 & $2.15(1.55-2.97)$ \\
\hline \multirow{2}{*}{ Stroke } & $\mathrm{P}$ & 7.24 & 8.45 & 20.88 & 15.56 & 22.22 \\
\hline & $\mathrm{PR}^{*}(95 \% \mathrm{Cl})$ & $1.43(0.97-2.10)$ & 1.00 & & 1.00 & $1.43(0.97-2.10)$ \\
\hline \multirow{2}{*}{ Asthma } & $P$ & 4.96 & 6.23 & 6.39 & 3.99 & 7.53 \\
\hline & $\mathrm{PR}^{*}(95 \% \mathrm{Cl})$ & $1.9(1.24-2.89)$ & 1.00 & & 1.00 & $1.90(1.24-2.89)$ \\
\hline \multirow{2}{*}{ Rheumatism } & $P$ & 4.88 & 6.31 & 20.00 & 15.27 & 22.04 \\
\hline & $\mathrm{PR}^{*}(95 \% \mathrm{Cl})$ & $1.46(1.18-1.80)$ & 1.00 & & 1.00 & $1.46(1.18-1.80)$ \\
\hline \multirow{2}{*}{$\begin{array}{l}\text { Spine/back } \\
\text { problem }\end{array}$} & $\mathrm{P}$ & 21.34 & 22.21 & 16.09 & 11.34 & 17.92 \\
\hline & $\mathrm{PR}^{*}(95 \% \mathrm{Cl})$ & $1.63(1.40-1.89)$ & 1.00 & & 1.00 & $1.63(1.40-1.89)$ \\
\hline \multirow{2}{*}{ WMSD } & $\mathrm{P}$ & 2.14 & 3.49 & 17.59 & 11.50 & 21.25 \\
\hline & $\mathrm{PR}^{*}(95 \% \mathrm{Cl})$ & $1.82(1.27-2.63)$ & 1.00 & & 1.00 & $1.82(1.27-2.63)$ \\
\hline \multirow{2}{*}{ Lung disease } & $\mathrm{P}$ & 1.65 & 1.72 & 14.00 & 10.73 & 15.27 \\
\hline & $\mathrm{PR}^{*}(95 \% \mathrm{Cl})$ & $1.48(0.90-2.45)$ & 1.00 & & 1.00 & $1.48(0.90-2.45)$ \\
\hline \multirow{2}{*}{ Cancer } & $\mathrm{P}$ & 2.10 & 3.78 & 11.09 & 6.41 & 14.26 \\
\hline & $\mathrm{PR}^{*}(95 \% \mathrm{Cl})$ & $2.09(1.30-3.34)$ & 1.00 & & 1.00 & $2.09(1.30-3.34)$ \\
\hline \multirow{2}{*}{$\begin{array}{l}\text { Kidney } \\
\text { disease }\end{array}$} & $\mathrm{P}$ & 1.42 & 1.59 & 12.17 & 7.60 & 14.07 \\
\hline & $\mathrm{PR}^{\star}(95 \% \mathrm{Cl})$ & $1.60(0.85-3.01)$ & 1.00 & & 1.00 & $1.60(0.85-3.01)$ \\
\hline
\end{tabular}

1.22-2.89), heart disease (PR 2.15; 95\%CI 1.55-2.97), stroke (PR 1.43; 95\%CI 0.97-2.1), asthma (PR 1.90; 95\%CI 1.24-2.89), rheumatism (PR 1.46; 95\%CI 1.18-1.80), back problems (PR 1.63; 95\%CI 1.40-1.89), WMSD (PR 1.82; 95\%CI 1.27-2.63), chronic lung disease (PR 1.48; 95\%CI 0.90-2.45), cancer (PR 2.09; 95\%CI 1.30- 3.34), and kidney disease (PR 1.6; 95\%CI 0.85-3.01). Again, individuals without health insurance had higher limitations prevalence for all NCDs. 


\section{DISCUSSION}

88,531 individuals aged over 18 years old were evaluated. Of these, $47.6 \%$ reported having at least one NCD, among the 11 diseases included. These diseases were more prevalent among women, individuals with black or brown race/color, illiterate or with incomplete primary education, in the Southeast and South regions, among individuals who do not have a private health insurance and with lower income. In general, there were more reports of limitations resulting from NCDs among those with less education and who did not have a private health insurance.

This study showed a high prevalence of NCDs in Brazil, where almost half of the population reported having at least one disease, which reflects a challenge for the health system and for the economy, considering that these diseases are responsible for most of the expenses for both treatment and prevention ${ }^{14}$. The prevalence and burden of NCD are the highest in several countries ${ }^{15-17}$. It is estimated that the global burden of NCDs will increase by $17 \%$ in the next decade ${ }^{18}$.

The prevalence of NCDs was higher for females when compared to males. Possible explanations may be related to the greater access of women to health services in Brazil when compared to men, which may favor early diagnosis and treatment ${ }^{19,20}$. Women also have a greater perception of the symptoms and physical signs of diseases, which results in greater demand for and use of health services ${ }^{19,21}$. Furthermore, there is the influence of scientific and care developments ${ }^{22}$, with the recognition of differences between genders regarding the clinical

presentations of these diseases, given the hormonal, functional, and emotional aspects ${ }^{22,23}$.

There is a direct relationship between the epidemiological and demographic transition processes, once that, as the number of aged people grows and life expectancy increases, NCDs also become more frequent ${ }^{24}$, as found in the present study, which showed that diseases were more prevalent in the people aged 65 years old and older. The association between advancing age and progressive increase in NCDs is based in the literature, especially on the inherent alterations of senescence ${ }^{25}$. In addition, longevity can also provide longer exposure to risk factors, such as pollution, smoking, unhealthy diet, and sedentary lifestyle ${ }^{26}$, contributing to the development of these diseases. In addition, aged people use health services more often, which can contribute to diagnosis ${ }^{13,20,27}$.

NCDs were more prevalent in the Southeast and South regions. Although adjusted by region and age, these regions have distinct age structures and a greater concentration of aged people, wealth, and jobs ${ }^{28,29}$. In addition, the South and Southeast have greater availability of health services and a greater proportion of individuals with health insurance, which can favor the diagnosis and identification of these diseases ${ }^{30}$.

This study showed greater magnitude of NCDs in black or brown individuals, illiterate or with incomplete primary education and who do not have a private health insurance and with lower income. There was also a greater report of limitations in usual activities among those with less education and who did not have private health insurance. These results show the impact of sociodemographic inequalities on the occurrence of NCDs. Social determinants, 
such as income, education, and environment, contribute to the increase and severity of NCDs and morbidity and mortality ${ }^{31}$, as low-income or socially disadvantaged individuals are more exposed to risk factors, have less access to health services, reducing opportunities for prevention and health promotion, as well as treatment for these diseases ${ }^{32,33}$. Other studies have shown that the prevalence of smoking and arterial hypertension were higher among adults with lower education ${ }^{33,34}$, as well as the prevalence of obesity ${ }^{35}$. On the other hand, the consumption of healthy foods and the practice of physical activity were higher among individuals with better education levels ${ }^{33-35}$. However, for some unhealthy foods, such as sweets, sandwiches, snacks, and pizzas, there was a higher prevalence in the more favored social segments and in white individuals ${ }^{36}$. A study analyzed the degree of socioeconomic disparities in the prevalence of health behaviors in the Brazilian population, according to the 2013 PNS. The results revealed significant social inequalities among Brazilian adults, as the less educated, non-white, and without private health insurance showed a higher prevalence of smoking, physical inactivity, and low intake of healthy foods such as vegetables and fruits. In addition, non-white individuals consumed more alcoholic beverages ${ }^{37}$. Other studies have also shown that the population with private health insurance had a lower prevalence of NCDs and limitations, which is justified by having more access to health services, tests, and treatments ${ }^{37-39}$. In general, the poorest population has more morbidity and $\mathrm{NCD}^{7}$, which reflects the country's socioeconomic disparities and reinforces the importance of investing in the Unified Health System (Sistema Único de Saúde - SUS) to promote opportunities for access to health services, diagnosis, and treatment of NCD for the most vulnerable population.

Hypertension was the most prevalent disease found in this study and is associated with more serious outcomes, such as cardiovascular diseases (CVD), cerebrovascular diseases, and renal failure ${ }^{39,40}$. Diabetes is a global public health problem, and its prevalence is increasing in Brazil and worldwide ${ }^{41}$. Chronic back problems and WMSD can affect a large portion of the population and represent one of the main causes of years of life lost due to limitation, resulting in an economic impact and on the quality of life of individuals ${ }^{42,43}$. Cancer and asthma were less prevalent in less educated individuals, showing an inverted gradient, which may be due to socioeconomic conditions, lower access to health services, and diagnosis among individuals with worse socioeconomic conditions ${ }^{16}$.

Socioeconomic inequalities in health indicators or risk factors for NCDs, as well as in the occurrence of diseases and limitations, highlight the importance of monitoring these inequalities as part of national health policies and the need to prioritize health promotion and prevention actions of health problems, in addition to expanding and improving the capacity to access and offer health services for the diagnosis and treatment of NCDs, especially among the most vulnerable social strata ${ }^{37}$.

Some limitations of the study should be considered, such as the impossibility of establishing a causal relationship, as this is a cross-sectional study. Because the 2019 PNS collects self-reported information, data may be subject to information bias. It is possible that the prevalence of some diseases is underestimated due to memory issues, the informant's ignorance or lack of medical diagnosis of the disease. The accuracy in measuring NCDs may 
differ according to the type of morbidity, with greater validity of information on diseases that require greater control. The informant's social characteristics can also impact the information ${ }^{44}$. Thus, results must be interpreted cautiously. However, it is noteworthy that the study was carried out in a representative sample of Brazilian adults, and the generalization of the results is safe for national estimates. The study also values high methodological rigor in the various stages of conduction and was carried out with a database that allows adjustments for potential confounding.

Results showed that about half of the Brazilian adult population reports a diagnosis of some NCD and evidenced that there are socioeconomic inequalities related to the prevalence of these diseases and, above all, to their limitations. Greater magnitude of prevalence of NCDs occurred among individuals with black or brown race/color, illiterate, with incomplete elementary/middle education, who do not have private health insurance and with lower income.

Although access to diagnosis can increase the prevalence of NCDs in the most advantaged population, this study detected significant associations that disadvantage the most vulnerable population. Expanding access is important to reduce inequalities in the treatment and control of NCDs in this population. Furthermore, improving the quality of health promotion services is essential for this reduction. Thus, the expansion of SUS needs to increasingly focus on the prevention and control of NCDs, with special attention to the impact of morbidities on individuals' daily activities. Strategies to prevent risk factors must be reinforced and continued, especially in primary care. The limitations were more frequent in the most vulnerable population and reinforce the importance of intersectoral actions to deal with NCDs. PNS data contribute to the identification of inequities and support public policies to overcome them. The importance of SUS in accessing health services and the opportunity for diagnosis and treatment of the most vulnerable populations is also highlighted.

\section{REFERENCES}

1. World Health Organization. Global status report on noncommunicable diseases 2010. Geneva: World Health Organization; 2011.

2. World Health Organization. Noncommunicable diseases country profiles 2018 Geneva: World Health Organization; 2018.

3. Malta DC, Duncan BB, Schmidt MI, Teixeira R, Ribeiro ALP, Felisbino-Mendes MS, et al. Trends in mortality due to non-communicable diseases in the Brazilian adult population: national and subnational estimates and projections for 2030. Popul Health Metrics 2020; 18: 16. https://doi.org/10.1186/ s12963-020-00216-1
4. Schmidt MI, Duncan BB, Silva GA, Menezes AM, Monteiro CA, Barreto SM, et al. Chronic noncommunicable diseases in Brazil: burden and current challenges. Lancet 2011; 377 (9781): 1949-61. https: / / doi.org/10.1016/S0140-6736(11)60135-9

5. World Health Organization. 'Best buys' and other recommended interventions for the prevention and control of noncommunicable diseases. Geneva: World Health Organization; 2017.

6. Abegunde DO, Mathers CD, Adam T, Ortegon M, Strong $\mathrm{K}$. The burden and costs of chronic diseases in lowincome and middle-income countries. Lancet 2007; (370): 1929-38. https: / / doi.org/10.1016/S0140-6736(07)61696-1 
7. Malta DC, Bernal RT, Souza MF, Szwarcwald CL, Lima MG, Barros MB. Social inequalities in the prevalence of self-reported chronic non-communicable diseases in Brazil: national health survey 2013. Int J Equity Health 2016; 15 (1): 153. https: / / doi.org/10.1186/s12939-016-0427-4

8. Diez Roux AV. Investigating neighborhood and area effects on health. Am J Public Health 2001; 91 (11): 1783-9. https: / / doi.org/10.2105/ajph.91.11.1783

9. Pampel FC, Krueger PM, Denney JT. Socioeconomic disparities in health behaviors. Annu Rev Sociol 2010; 36: 349-70. https://doi.org/10.1146/annurev.soc.012809.102529

10. Malta DC, Silva MMA, Moura L, Morais Neto OL. A implantação do Sistema de Vigilância de Doenças Crônicas Não Transmissíveis no Brasil, 2003 a 2015: alcances e desafios. Rev Bras Epidemiol 2017; 20(4): 66175. https: / / doi.org/10.1590/1980-5497201700040009

11. United Nations. Transforming our world: the 2030 agenda for sustainable development. General Assembly [Internet]. 2015 [cited on March 7, 2021]. Available at: https: / / www.un.org/ga/search/view_doc. asp?symbol=A/RES $/ 70 / 1 \&$ Lang $=\mathrm{E}$

12. Instituto Brasileiro de Geografi a e Estatística. Pesquisa nacional de saúde: 2019: percepção do estado de saúde, estilos de vida, doenças crônicas e saúde bucal: Brasil e grandes regiões/IBGE, coordenação de trabalho e rendimento. Rio de Janeiro: IBGE; 2020.

13. Stopa SR, Malta DC, Monteiro CN, Szwarcwald CL, Goldbaum M, Cesar LGC. Acesso e uso de serviços de saúde pela população brasileira, Pesquisa Nacional de Saúde 2013. Rev Saude Publica 2017; 51 (Suppl 1): 3s. http: / / doi.org/10.1590/s1518-8787.2017051000074

14. Kwon SH, Myong JP, Kim HA, Kim KY. Association between morbidity of non-communicable disease and employment status: a comparison between Korea and the United States. BMC Public Health 2020 24; 20 (1): 763. http:/ / doi.org/10.1186/s12889-020-08883-3

15. World Health Organization. Global status report on noncommunicable diseases 2014. Geneva: World Health Organization; 2014.

16. Dalstra JA, Kunst AE, Borrell C, Breeze E, Cambois E, Costa G, et al. Socioeconomic differences in the prevalence of common chronic diseases: an overview of eight European countries. Int J Epidemiol 2005; 34 (2): 316-26. http: / / doi.org/10.1093/ije/dyh386

17. Mao W, Zhang Y, Xu L, Miao Z, Dong D, Tang S. Does health insurance impact health service utilization among older adults in urban China? A nationwide cross-sectional study. BMC Health Serv Res 2020; 20 (1): 630. http:/ / doi.org/10.1186/s12913-020-05489-8

18. Wang Y, Wang J. Modelagem e previsão de doenças não transmissíveis globais. BMC Public Health 2020; 20: 822. https: / / doi.org/10.1186/s12889-020-08890-4
19. Malta DC, Bernal RTI, Lima MG, Araújo SSC, Silva MMAD, Freitas MIF, et al. Noncommunicable diseases and the use of health services: analysis of the National Health Survey in Brazil. Rev Saude Publica 2017; 51 (Suppl 1): 4s. http: / doi.org/10.1590/ S1518-8787.2017051000090

20. Szwarcwald CL, Stopa SR, Damacena GN, Almeida WS, Souza Júnior PRB, Vieira MLFP, et al. Mudanças no padrão de utilização de serviços de saúde no Brasil entre 2013 e 2019. Cien Saude Colet [Internet]. 2020 [cited on May 22, 2021]. Available at: https://www. cienciaesaudecoletiva.com.br/artigos/mudancas-nopadrao-de-utilizacao-de-servicos-de-saude-no-brasilentre-2013-e-2019/17864?id=17864

21. Travassos C, Martins M. Uma revisão sobre os conceitos de acesso e utilização de serviços de saúde. Cad Saude Publica 2004; 20 (Supl 2): 190-8. https: / doi. org/10.1590/S0102-311X2004000800014

22. Saeed A, Kampangkaew J, Nambi V. Prevention of cardiovascular disease in women. Methodist Debakey Cardiovasc J 2017; 13 (4): 185-92. https:/ / doi.org/10.14797/mdcj-13-4-185

23. Zhang Y, Liu B, Zhao R, Zhang S, Yu XY, Li Y. The influence of sex on cardiac physiology and cardiovascular diseases. J Cardiovasc Transl Res 2020; 13 (1): 3-13. https:/ / doi.org/10.1007/s12265-019-09898-x

24. SchrammJMA, Oliveira AF, Leite IC, Valente JG, Gadelha AMJ, Portela MC, et al. Transição epidemiológica e o estudo de carga de doença no Brasil. Cienc Saude Coletiva 2004; 9 (4): 897-908. https: / / doi.org/10.1590/ S1413-81232004000400011

25. Massa KHC, Duarte YAO, Chiavegatto Filho ADP. Análise da prevalência de doenças cardiovasculares e fatores associados em idosos, 2000-2010. Cienc Saude Coletiva 2019; 24 (1): 105-14. https:// doi. org/10.1590/1413-81232018241.02072017

26. Costantino S, Paneni F, Cosentino F. Ageing, metabolism and cardiovascular disease. J Physiol 2016; 594 (8): 2061-73. https://doi.org/10.1113/ JP270538

27. Louvison MCP, Lebrão ML, Duarte YAO, Santos JLF, Malik AM, Almeida ES. Desigualdades no uso e acesso aos serviços de saúde entre idosos do município de São Paulo. Rev Saude Publica 2008; 42 (4): 733-40. https:// doi.org/10.1590/ S0034-89102008000400021

28. Instituto Brasileiro de Geografia e Estatística (IBGE). Pesquisa Nacional por amostra de domicílios. Um panorama da saúde no Brasil. Acesso e utilização de serviços, condições de saúde e fatores de risco e proteção à saúde 2008. Rio de Janeiro: IBGE; 2010. 
29. Instituto Brasileiro de Geografia e Estatística (IBGE). Censo Demográfico 2010. Características gerais da população, religião e pessoas com deficiência. Rio de Janeiro: IBGE; 2012.

30. Malta DC, Stopa SR, Pereira CA, Szwarcwald CL, Oliveira M, Reis ACD. Cobertura de planos de saúde na população brasileira, segundo a Pesquisa Nacional de Saúde, 2013. Cienc Saude Colet 2017; 22 (1): 179-90. https: / / doi.org/10.1590/1413-81232017221.16782015

31. Marmot M, Bell R. Social determinants and noncommunicable diseases: time for integrated action. BMJ 2019; 364: 1251. https: / / doi.org/10.1136/bmj.1251

32. Keetile M, Navaneetham K, Letamo G, Rakgoasi SD. Socioeconomic inequalities in non-communicable disease risk factors in Botswana: a cross-sectional study. BMC Public Health 2019; 19 (1): 1060. https: / / doi.org/10.1186/s12889-019-7405-x

33. Malta DC, Moura EC, Morais Neto OL. Desigualdades de sexo e escolaridade em fatores de risco e proteção para doenças crônicas em adultos Brasileiros, por meio de inquéritos telefônicos. Rev Bras Epidemiol 2011; 14 (Suppl 1): 125-35. http:// doi.org/10.1590/ S1415-790X2011000500013

34. Francisco PMSB, Segri NJ, Barros MBA, Malta DC. Desigualdades sociodemográficas nos fatores de risco e proteção para doenças crônicas não transmissíveis: inquérito telefônico em Campinas, São Paulo. Epidemiol Serv Saude 2015; 24 (1): 7-18. http:/ / doi. org/10.5123/S1679-49742015000100002

35. Silva AG, Teixeira RA, Prates EJS, Malta DC. Monitoramento e projeções das metas de fatores de risco e proteção para o enfrentamento das doenças crônicas não transmissíveis nas capitais brasileiras. Cienc Saude Coletiva 2021; 26 (4): 1193-206. https: / / doi.org/10.1590/1413-81232021264.42322020

36. Medina LPB, Barros MBA, Sousa NFS, Bastos TF, Lima MG, Szwarcwald CL. Desigualdades sociais no perfil de consumo de alimentos da população brasileira: Pesquisa Nacional de Saúde, 2013. Rev Bras Epidemiol 2019; 22 (Suppl 2): E190011.SUPL.2. https: / / doi.org/10.1590/1980-549720190011.supl.2

37. Barros MBA, Lima MG, Medina LP, Szwarcwald CL, Malta DC. Social inequalities in health behaviors among Brazilian adults: National Health Survey, 2013. Int J Equity Health 2016; 15 (1): 148. https:// doi.org/10.1186/s12939-016-0439-0

38. Malta DC, Bernal RTI, Oliveira M. Tendências dos fatores de risco de doenças crônicas não transmissíveis, segundo a posse de planos de saúde, Brasil, 2008 a 2013. Cienc Saude Coletiva 2015; 20 (4): 1005-16. http:/ / doi.org/10.1590/1413-81232015204.14712014

39. Ribeiro MCSA, Barata RB, Almeida MF, Silva ZP. Perfil sociodemográfico e padrão de utilização de serviços de saúde para usuários e não-usuários do SUS - PNAD 2003. Cienc Saude Coletiva 2006; 11 (4): 1011-22. https: / / doi.org/10.1590/S1413-81232006000400022

40. Oliveira GMM, Brant LCC, Polanczyk CA, Biolo A, Nascimento BR, Malta DC, et al. Estatística cardiovascular - Brasil 2020. Arq Bras Cardiol 2020; 115(3): 308-439. http:// doi.org/10.36660/abc.20200812

41. Shaw JE, Sicree RA, Zimmet PZ. Global estimates of the prevalence of diabetes for 2010 and 2030. Diabetes Res Clin Pract 2010; 87 (1): 4-14. http: / / doi. org/10.1016/j.diabres.2009.10.007

42. Oliveira MM, Andrade SSCA, Souza CAV, Ponte JN, Szwarcwald CL, Malta DC. Problema crônico de coluna e diagnóstico de distúrbios osteomusculares relacionados ao trabalho(DORT) autorreferidos no Brasil: Pesquisa Nacional de Saúde, 2013. Epidemiol Serv Saúde 2015; 24 (2): 28796. https:// doi.org/10.5123/S1679-49742015000200011

43. Romero DE. Muzy J, Maia L, Marques AP, Souza Júnior PRBD, Castanheira D. Desigualdades e fatores associados ao tratamento do problema crônico de coluna no Brasil. Cienc Saude Coletiva 2019; 24 (11): 4211-26. https: / doi.org/10.1590/1413-812320182411.06352018

44. Okura Y,Urban LH, Mahoney DW,Jacobsen SJ, Rodeheffer RJ. Agreement between self-report questionnaires and medical record data was substantial for diabetes, hypertension, myocardial infarction and stroke but not for heart failure. J Clin Epidemiol 2004; 57 (10):1096-103.

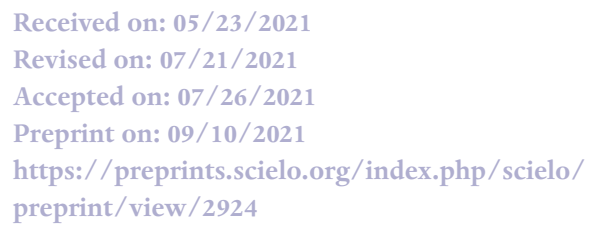

Authors' contributions: DCM: conceptualization, data curation, formal analysis, writing - first draft, writing - proofreading and editing. RTIB: conceptualization, data curation, formal analysis, writing - first draft, writing - proofreading and editing. MGL: conceptualization, data curation, formal analysis, writing - first draft, writing - proofreading and editing. AGS: conceptualization, data curation, formal analysis, writing - first draft, writing-proofreading and editing. CLS: conceptualization, data curation, formal analysis, writing - first draft, writing proofreading and editing. MBAB: conceptualization, data curation, formal analysis, writing - first draft, writing - proofreading and editing.

(C) 2021 Associação Brasileira de Saúde Coletiva This is an open access article distributed under the terms of the Creative Commons license. 